\title{
TOŻSAMOŚĆ EUROPEJSKA JAKO PROBLEM HISTORII I WSPÓŁCZESNOŚCI
}

\author{
„Podstawą jedności Europy jest \\ idea wspólnoty chrześcijańskiej, \\ kultura i cywilizacja europejska"
}

Konrad Adenauer

„[... jeśli Europa nie będzie miała swojej duszy,

sama nie określi się kulturowo, nie będzie Europą.

A jeśli będzie tylko wspólnotą polityczną czy ekonomiczną, to absolutnie nie spełni swojego zadania"

Jacques Delors

„Europa nigdy nie istniała.

Europę naprawdę trzeba stworzyć"

Jean Monnet

Opracowanie traktuje o tożsamości europejskiej, nie zaś o tożsamości społeczeństw czy zbiorowości Unii Europejskiej. Uwaga taka ma znaczenie o tyle, o ile ta pierwsza ma jakieś zakorzenienie w tradycji i historii, druga natomiast oparcie zyskuje $\mathrm{w}$ zaawansowanych procesach integracyjnych przejawiających się przede wszystkim w gospodarce, porządku prawnym i politycznym, zatem w dziedzinach życia społecznego obecnie najważniejszych, nieposiadających jednak zakorzenienia w tradycjach kulturowych. Podstawą integracji w Europie nie stała się sfera kultury, jak sobie tego życzyli Ojcowie Założyciele Europy, lecz ekonomia i polityka, a te prowadzić mogą do wytworzenia wspólnoty interesów, nie będąc zarazem podstawą wykształcenia się tożsamości mieszkańców kontynentu. Niski stopień identyfikacji społeczeństw europejskich ze wspólnotą europejską w opozycji do ich znacznie wyraźniejszej identyfikacji narodowej skłania sterników Unii Europejskiej do zamysłów konstruowania czy wytwarzania tożsamości wspólnej w oparciu o obecne osiągnięcia, a nie o przeszłe doświadczenia. Wysiłki takie mają miejsce wskutek procesu jednoczenia właśnie. Społeczeństwa znajdujące się poza Unią, jak Szwajcarzy, nie przeżywają podobnych problemów. Tak zwana tożsamość konstruktywistyczna 
definiowana jako próba jej wytworzenia na nietożsamym gruncie w odróżnieniu od tożsamości rozumianej w tradycyjnym i utartym sensie słowa stanowi w tym opracowaniu jedną, i to niewielkich rozmiarów, część. Cała reszta dowodzi istnienia i historycznych przemian tożsamości europejskiej, zakorzenionej we wzorach kultury i chrześcijańskim dziedzictwie.

\section{Czym jest tożsamość zbiorowa}

Jak dobrze wiadomo, pojęcie tożsamości, zarówno indywidualnej, jak i zbiorowej, jest terminem wyjątkowo nieostrym, trudnym do zdefiniowania. ${ }^{1}$ Przeświadczenie o posiadaniu tożsamości przez jakikolwiek byt ludzki, indywidualny czy zbiorowy jest, jak powiada Hayden White, wytworem humanistycznej kultury nowożytnego Zachodu, choć pojęcie to jest nie mniej mgliste niż pojęcie trójjedynego Boga. ${ }^{2}$

W zaproponowanej poniżej definicji pomija się pojęcie tożsamości indywidualnej, a w wypadku tożsamości kolektywnej bierze się pod uwagę wyłącznie takie jej rodzaje, jak tożsamość religijna (parafii, Kościoła, kongregacji, sekty), etniczna (narody, grupy etniczne, mniejszości narodowe), regionalna (zbiorowości lokalne, regionalne, miasta, wsie, osiedla) i, wreszcie, tożsamość kulturowo-cywilizacyjna, jak właśnie tożsamość europejska, ale też np. środkowoeuropejska, wschodnioazjatycka, arabska itp. We wszystkich wyszczególnionych przypadkach mamy do czynienia $z$ sytuacją, kiedy jednostka definiuje siebie poprzez przynależność do jakiejś zbiorowości, która $\mathrm{z}$ tego właśnie powodu ma dla niej znaczenie szczególne, a nie powierzchowne czy przelotne. To znaczenie przymusza jednostkę do deklaracji typu: jestem katolikiem, kwakrem, jestem Belgiem, Cyganem, Krakusem, Ślązakiem, Europejczykiem, konfucjanistą itp.

Cechą wszystkich wyróżnionych powyżej rodzajów zbiorowości jest silne zakotwiczenie w historii i równie silna więź emocjonalna na bazie wspólnych wartości i symboli przynależności. Te cechy nie charakteryzują zbiorowości hydraulików, akcjonariuszy spółki akcyjnej, masonów, członków partii politycznej czy związku zawodowego. $Z$ tych racji poniżej podana definicja tożsamości zbiorowej pomija te zbiorowości, włączając w swój zakres całkowicie i bez wyjątku wyłącznie te związki

1 Przegląd tych trudności oraz stanowisk przyjmowanych w definiowaniu tożsamości zawiera praca Z. Bokszańskiego, Tożsamości zbiorowe, PWN, Warszawa 2005, zwłaszcza rozdz. 2 i 3.

2 H. White, Dyskurs europejski i poszukiwanie europejskiej tożsamości, w: Postcolonial Europe, http:// www.postcolonial-europe.eu/index.php/pl/essays/93-dyskurs-europejski-i-poszukiwanie-europejskiejtosamoci 
społeczne, których przykłady zostały podane akapit wyżej. Od czasów Ferdynanda Toenniesa zbiorowości jednostek oparte na łączności tradycyjno-emocjonalnej określamy mianem wspólnot, a związki społeczne na bazie racjonalnej kalkulacji - mianem stowarzyszeń. ${ }^{3}$ Jest oczywiste, że identyfikacja jednostki ze zrzeszeniem okazuje się zawsze płytsza niż jej identyfikacja ze wspólnotą. Poniższa definicja tożsamości zbiorowej obejmuje swoim zakresem wyłącznie wspólnoty. Jest to uzasadnione przedmiotem opracowania, czyli przemianami tożsamości europejskiej, a ta była historycznie oparta na wspólnocie i dziś jeszcze opisuje się ją, choć na wyrost, jako wspólnotę, a nie zrzeszenie państw czy obywateli.

Zatem definicja tożsamości zbiorowej w odniesieniu do wspólnoty jest następująca: tożsamość, czyli identyfikacja zbiorowa oznacza podstawowe (niepowierzchowne, trwałe) podobieństwo członków wspólnoty pozwalające im na definiowanie własnej wspólnoty jako bytu społecznego, do którego jednostki przynależą z poczuciem odrębności wobec świata zewnętrznego. Cechami tak pojmowanej tożsamości są aprobujące świadomość przynależności, wspólnie podzielane wartości i normy oraz wspólne interesy, które często okazują się ważniejsze niż interesy indywidualne. Tożsamość zbiorowa powstaje wówczas, gdy świadome stają się cechy wspólne, a własna wspólnota zostaje odgraniczona od innych. Tożsamość jest cechą nieodłączną wspólnoty, co oznacza, że nie istnieje żadna wspólnota, w której poczucie tożsamości nie byłoby obudzone. Związek społeczny bez oparcia w tożsamości nie jest wspólnotą.

Tożsamość nie jest tworem jednostki, lecz dziedzictwem, które poprzedza egzystencję jednostki, nadaje jej poczucie bezpieczeństwa i zakorzenienia. Jednostka nie tworzy swej tożsamości zbiorowej, ani jej nie wybiera, kształtuje ją wspólnota właśnie. W świadomości uczestników wspólnoty tożsamość stanowi podstawę wyjaśniania i oceny rzeczywistości zewnętrznej, które zawsze dokonują się z jakiegoś punktu widzenia czy odniesienia.

W przeszłości istniejące wspólnoty oparte były, wszystkie bez wyjątku, na wyraźnym przeciwstawieniu „swoich” i „obcych”. Wspólnota zawsze była „nasza”, świat poza wspólnotą był zawsze „obcy”. Istnienie wspólnot opozycyjnych wzmacniało siłę wspólnoty własnej, solidarność uczestników, ich przywiązanie i wewnętrzne przeżycie przynależności. Zbiorowość bez poczucia własnej tożsamości przetrwać nie może. Tożsamość jest niezbędna dla jej egzystencji. ${ }^{4}$ Także w naturze zrzeszeń, związków kontrastowo odmiennych od wspólnot, nie leży w ogóle partycypacja wszystkich.

${ }^{3}$ F. Tönnies, Wspólnota i stowarzyszenie. Rozprawa o komunizmie i socjalizmie jako empirycznych formach kultury, PWN, Warszawa 2008.

4 B. Skarga, Zbiorowa tożsamość i zagrożenia z nia związane, „Kultura i Społeczeństwo” 1998, nr 3, s. 3-4. 
Od samych początków zrzeszenia tworzyły się, inaczej niż wspólnoty, wewnątrz jakichś społecznych całości, pozostając świadectwem podziałów wewnętrznych. Jest możliwy naród jako wspólnota, natomiast partia ogólnonarodowa jako zrzeszenie zaprzecza samej sobie i własnemu określeniu jako partii. Silna wspólnota narodowa może trwać i rozwijać się pod warunkiem istnienia innych wspólnot narodowych. Wspólnota ponadnarodowa jest możliwa do pomyślenia także pod warunkiem istnienia przeciwstawnych wspólnot narodowych bądź ponadnarodowych. Elementy przeciwieństwa, opozycji wydają się niezbywalnym warunkiem kształtowania wspólnoty i jej tożsamości.

Warte dodania do przedstawionej definicji tożsamości zbiorowej są wyznaczniki geograficzne, historyczne i etnologiczne w ujęciu tożsamości zbiorowej. Pierwszy odsyła do przestrzennego przypisania, gdyż na ogół wspólnota (etniczna, religijna, terytorialna) rozwija się na ograniczonym terytorium, choć znane są wypadki efektywnej trwałości wspólnoty bez spełnienia tego geograficznego warunku, jak Żydzi przez większą część swojej historii. W perspektywie historycznej uczestnicy wspólnoty odnoszą się do jej dziejów, a w perspektywie etnologicznej przechowują dziedzictwo kulturowe, rozumienie znaczeń i symboli.

Dodatkowo należy podkreślić walor pamięci w ujęciu identyfikacji zbiorowej. Eric Erikson definiuje nawet tożsamość jako „subiektywne poczucie ciągłości istnienia objęte wspólną pamięcią." W swoim eseju o tożsamości zbiorowej Leszek Kołakowski ujmuje ten czynnik jako składnik tożsamości ważniejszy niż język. Zbiorowość może utracić swój język, jak Irlandczycy czy Żydzi w przeszłości, nie tracąc tożsamości. Pamięć bytów zbiorowych jest warunkiem ich ciągłości; nie miałoby sensu mówienie o niej, gdyby cały zasób pamięci został wymazany. ${ }^{6}$ Zastosowanie tego dowodzenia do wysiłków skonstruowania tożsamości europejskiej wykazuje beznadziejność takiego przedsięwzięcia. Skoro Europa, jak się dowodzi, nie ma tożsamości, gdyż nie ma pamięci historycznej, to wysiłek zbudowania tożsamości jest daremny dopóty, dopóki pamięć europejska nie zostanie ugruntowana. Innymi słowy, jest możliwe spontaniczne wytworzenie się takiej tożsamości po upływie jakiegoś czasu, nie jest możliwe skonstruowanie świadomości zbiorowej i następnie nałożenie jej na zbiorowość. Obecnie elity europejskie posługują się technologiami wytwarzania tożsamości celem stymulacji tożsamości zbiorowej.

Tożsamość zbiorowa nie jest niezmienna. Naród, wspólnota regionalna, konfesja religijna zmieniają w toku historii swoją tożsamość, co oznacza, że same się zmieniają.

${ }^{5}$ E.H. Erikson, Identity, w: International Encyclopedia of the Social Science, Vol. 7, Macmillan, London 1968, s. 61.

${ }^{6}$ L. Kołakowski, O tożsamości zbiorowej, w: L. Kołakowski, Moje słuszne poglądy na wszystko, Wydawnictwo Znak, Kraków 1999, s. 158. 
W wiekach XVI-XVII purytanie stanowili wspólnotę o nadzwyczajnym stężeniu wrażliwości religijnej, a przy tym sztywną i nietolerancyjną. Obecnie są znani z ducha tolerancyjnego i akceptacji religijnego nowinkarstwa. W przeszłości Szwedzi byli znani z wypraw łupieżczych i zagarniania cudzych terytoriów. Tożsamość imperialną odrzucili w XVIII wieku po bitwie pod Połtawą i utracie armii. Zaczęli wówczas budować nową tożsamość narodową na zupełnie odmiennych wartościach. ${ }^{7}$ W obecnych czasach Żydzi są znani jako wyśmienici żołnierze, a Niemcy jako kupcy i handlarze. A przecież przed II wojną światową narody te ujawniały cechy całkiem na przemian odmienne. Mimo to jedni i drudzy pozostali sobą.

W swoim tradycyjnym znaczeniu pojęcie „tożsamość” oznacza istotę, która pozostaje taka sama niezależnie od wszelkiego rodzaju doświadczeń, takich jak choćby religijne nawrócenie czy odrodzenie, renesans czy reformacja, które jednostka bądź grupa ludzi przeżyć może w trakcie swej historii. Tak pojmowana tożsamość jest rodzajem esencji, która objawia się w każdej części, w każdym aspekcie i elemencie danej osoby lub grupy, nie sprowadzając się jednak do żadnej właściwej im cechy.

Naturalnie, zmiany tożsamości nie sprzyjają w ogólności jej utrwaleniu. Stwierdzić można, że siła tożsamości jest odwrotnie proporcjonalna do natężenia zmian we wspólnocie. Identyfikacja jest najsilniejsza, w sensie spajających jednostki więzi, tam, gdzie zmiany dokonują się z najwyższym trudem, jak w społeczności Amiszy, wykazujących nadzwyczajny opór wobec zmian. Zmiany powodują zwykle „rozwodnienie" tożsamości, a nierzadko jej rozłamanie na dwa (bądź nawet więcej) konkurencyjne ośrodki tożsamości. Są liczne na to przykłady, jak judaizm rabiniczny, chasydyzm i haskala jako konkurencyjne ośrodki integracji i tożsamości wśród Żydów europejskich w XVIII i XIX wieku ${ }^{8}$ czy u wspomnianych Amiszy tożsamości starego i nowego zakonu. ${ }^{9}$ Jeśli opisana zależność między tożsamością i zmianą jest trafna, to stwierdzić należy, że w dobie wyjątkowo szybkich zmian we wszystkich dziedzinach życia tożsamość, podobnie zresztą jak wspólnota, zdają się pozbawione trwałej podstawy społecznej, ulegając nazbyt często atrofii.

\footnotetext{
7 P. Englund Lata wojen: Połtawa, Finna, Gdańsk 2003; P. Englund, Niezwyciężony, Finna, Gdańsk 2004.

8 Por. J. Siewierski, Przemiany tożsamości Żydów europejskich w perspektywie historycznej, niepubl. oprac. z badań statutowych 2011 pod kier. E. Firlit.

9 Por. D. Dejna, Amisze - fenomen wychowania endemicznego, Wydawnictwo A. Marszałek, Toruń 2012; E. Wesner, Kim sq̨ amisze?, Verbinum, Warszawa 2012.
} 


\section{Tożsamość europejska jako problem}

Skłonni jesteśmy sądzić, że identyfikacja zbiorowości odwołujących się do racji kulturowych, religijnych, etnicznych, terytorialnych obejmuje swoim zasięgiem wspólnoty znacznych czasem rozmiarów, jak liczne narody Stanów Zjednoczonych, Rosji czy Chin, lecz objąć nie jest w stanie bytów ponadnarodowych ze względu na ich nadmierne zróżnicowanie wewnętrzne. A jednak Kościół katolicki, jak w ogóle wszelkie religie o zasięgu powszechnym, światowym stanowi użyteczny przykład wspólnoty samotożsamej, wewnętrznie różnorodnej, ale zachowującej równowagę i jedność, mimo występujących często napięć i tarć. Ten przykład dowodzi, że zbiorowości charakteryzujące się tożsamością mogą osiągać rozmiary nie tyle kontynentalne, ile planetarne.

Badacze cywilizacji nie mają wątpliwości, że kręgi cywilizacyjne charakteryzują się własną tożsamością i że właśnie w epoce nasilenia procesów globalizacyjnych stare cywilizacje są stymulowane do poszukiwań tych właściwości, które odróżniają je od pozostałych części globu. Tożsamość cywilizacyjna wzrasta właśnie wskutek ujednolicenia w rozwoju technologii, ekonomii, komunikacji i popkultury. Przy tym renesans tożsamości muzułmańskiej, hinduskiej, konfucjańskiej (w odmianie chińskiej i japońskiej) itp. dokonuje się poprzez sięganie do historycznie zakorzenionych tradycji i mitów, mających utwierdzić wartość własnych kultur wobec świata zewnętrznego. ${ }^{10}$ Kultura zachodnia, w tym europejska, uczestniczy w tym procesie na swój własny sposób, zupełnie niezrozumiały nawet dla obecnych promotorów „jedności europejskiej”.

W okresie, kiedy kultury niezachodnie odkrywają na nowo własne korzenie, Europa odcina pępowinę łączącą ją z własną tradycją i historią, oddala się od swoich korzeni. Historia kontynentu jest prezentowana jako hańbiąca $\mathrm{z}$ toksyczną zawartością kolonializmu, handlu niewolnikami, imperializmu, nacjonalizmu i reżimów totalitarnych. Europejska historia ma być powodem ekspiacji, za własną historię Europejczycy powinni się wstydzić i przepraszać „obcych”, co parę razy zresztą zrobili w ich imieniu przywódcy państw i rządów. To „barbarzyństwo” miałoby stanowić podstawę „cywilizacji” europejskiej. Z tego rodzaju podejścia wynika oczywista konkluzja, że tożsamości europejskiej, jeżeli w ogóle warto jej poszukiwać, nie należy opierać na historii, a ta jest przecież ściśle powiązana $\mathrm{z}$ tradycją kulturową.

10 Por. S.P. Huntington, Zderzenie cywilizacji i nowy kształt ładu światowego, Wydawnictwo Muza, Warszawa 2004. 
W jej miejsce zaproponowano Europejczykom ideę i politykę wielokulturowości, czyli rozumienie i poszanowanie kultur pozaeuropejskich.

Z pewnością czasy, w których Europa mogła uznawać własne doświadczenia i własną kulturę za normę, a inne kultury za wcześniejsze stadia jej rozwoju, bezpowrotnie minęły. To przekonanie było oparte, jak stwierdza Charles Taylor, na założeniach aroganckich. Ale, jak dodaje, otwierając się na inne kultury, wystawiamy się na ryzyko, że pomniejszymy znaczenie naszych własnych wartości. ${ }^{11} \mathrm{Na}$ tych samych łamach Frank Furedi dodawał, że przy proklamowaniu otwartości na inne kultury zabrakło akceptacji dla kultury własnej, która to akceptacja jest warunkiem wstępnym tolerancji, otwartości i różnorodności. W rezultacie dopuszczono coś w rodzaju intelektualnego promiskuityzmu. Samo bycie odrębnym stało się ważniejsze od bycia członkiem wspólnoty politycznej. ${ }^{12}$ Społeczeństwa europejskie przestały sobie zadawać pytania, kim są i w co wierzą. Kultura europejska nie jest już traktowana, co powinno martwić, jako atrakcyjny system wartości, ponieważ sami Europejczycy tak jej nie traktują. Niezależnie od konsekwencji praktykowania wielokulturowości dla podminowania tożsamości Europejczyków, sama ta polityka nie wywoływała, wbrew zapowiedziom, zgodnego współżycia kultur, lecz raczej konflikty stale się odnawiające przynajmniej w niektórych krajach europejskich.

Polityka wielokulturowości, podobnie jak próby skonstruowania tożsamości na nowo i wiele innych projektów narzucanych z Brukseli, to przykłady biurokratyczno-politycznych działań mających na celu racjonalne uporządkowanie skomplikowanej rzeczywistości społecznej drogą dyrektyw, z góry obmyślonych, planowanych i odgórnie narzucanych projektów. Tak mniej więcej, jak się wyznacza stawki celne, redukcję emisji dwutlenku węgla czy pożądany kształt banana. Zarówno organy UE, jak i rządy państw członkowskich czują się od dawna powołane do tworzenia i realizacji czegoś, co można określić jako racjonalny projekt, czyli projekt (program) podsuwany przez rozum i rzeczywiste potrzeby. W wyniku nadmiernej produkcji i realizacji takich projektów zamierają samoczynne mechanizmy społeczne i gospodarcze, które mogłyby rozwiązać problemy zdefiniowane w projekcie tańszym kosztem. Można zaryzykować opinię, że rząd poprzez potężne scentralizowane struktury biurokratyczne w coraz większej mierze zastępuje społeczeństwo i rynek w rozwiązywaniu niezliczonych problemów społecznych. Byłaby to rozsądna droga, gdyby rządy się nie myliły w swojej ocenie rzeczywistych problemów. Nie wypada jednak na to liczyć.

11 Koniec ideologii multikulturalizmu?, „Newsweek” 7 kwietnia 2007; wypowiedzi Taylora, Franka Furedi, Paula Bermana itp.

12 Ibidem. 
W zintegrowanej Europie nie ma już miejsca na procesy spontaniczne, dokonywane drogą prób i błędów, które z natury rzeczy są nieprzewidywalne, ale zakładają współuczestnictwo wielkich rzesz społecznych. Najważniejsze zdobycze społeczno-gospodarczych dziejów Europy, jak rynek, prawa jednostki czy demokracja, nie powstały przecież $\mathrm{w}$ drodze racjonalnego projektowania, lecz przez długie doświadczenia przejawiające się $\mathrm{w}$ „naturze” rozwoju. Także samorzutnie, a nie w wyniku planowania tworzyły się religie, obyczaje, autorytety, więzi duchowe. Poprzez wcielanie racjonalnych projektów w życie nieodwracalnemu zniszczeniu ulega powaga tradycji jako zbioru nauk, czasem też przesądów, nagromadzonych przez stulecia. Służyły one ludziom przez wieki jako niezawodna wskazówka i orientacja w życiu, stanowiły o zakorzenieniu jednostki. Oczywiste jest, że procesy rozwojowe podważały autorytet tradycji, jednakże współczesna innowacja polega na tym, że refutacja tradycji wynika z racjonalnych, wydumanych argumentów mędrkującego rozumu.

Konstrukcja nowej, niezależnej i oderwanej od historii tożsamości europejskiej to typowy racjonalny projekt, w którym nie bierze się pod uwagę życzeń i nastawienia zwykłych obywateli będących w zamierzeniu konsumentami tożsamości skonstruowanej. Początkowo zakładano, że nowa tożsamość będzie naturalnym produktem integracji. Tak się jednak nie stało, ponieważ „instytucje europejskie były budowane pod nieobecność »Europejczyków «". ${ }^{13}$ Stąd poszukiwania „prawdziwej tożsamości”, tzn. próby jej wymyślenia. ${ }^{14} \mathrm{~W}$ te próby zaangażowali się wybitni intelektualiści europejscy. Jacques Derrida i Jürgen Habermas we wspólnym tekście dowodzą, że tożsamość europejska musi mieć „coś z konstrukcji” ${ }^{15}$ Trudno jednak znaleźć elementy konstrukcyjne, ponieważ historyczne osiągnięcia Europy uległy uniwersalizacji, tzn. zostały przeniesione i zaakceptowane w pozaeuropejskich częściach świata: „[...] chrześcijaństwo i kapitalizm, nauki przyrodnicze i technika, prawo rzymskie i Kodeks Napoleona, mieszczański sposób życia i prawa człowieka, sekularyzacja państwa i społeczeństwa rozprzestrzeniły się na inne kontynenty, zdobycze te nie stanowią już europejskiego proprium" ${ }^{16}$ Proponują zatem jako budulec nowej tożsamości indywidualizm, racjonalizm, aktywizm i pluralizm rozumiany jako wzajemne uznawanie różnic. Te aspekty kulturowej rzeczywistości Europy nie są, naturalnie, respektowane w społeczeństwach pozazachodnich, nie stanowią jednak różnicy między Europą a pozaeuropejskimi społeczeństwami Zachodu. Pomimo włożonego wysiłku obaj znakomici autorzy nie znajdują żadnej podstawy, na której można zbudować

${ }^{13}$ L. Hooghe, G. Marks, Tożsamości wielorakie, „Nowa Europa. Przegląd Natoliński” 2007, nr 1(5), s. $56-83$.

14 H. White, op.cit.

15 J. Derrida, J. Habermas, Po wojnie: odrodzenie Europy, „Krytyka Polityczna” 2005, nr 5, s. 155.

16 Ibidem, s. 154. 
tożsamość europejską, uwolnioną od historii i tradycji, jednak z pomysłu konstrukcji tożsamości się nie wycofują.

Podobnie na deklaracjach zaczyna i kończy Zygmunt Bauman, stwierdzając, że tożsamość ,jawi się nam jako coś, co należy wytworzyć, a nie odkryć; jako przedmiot naszych wysiłków, a nie cel, do którego należy dojść, jako coś, co musimy dopiero skleić $\mathrm{z}$ części lub wybrać $\mathrm{z}$ dostępnych całości”. ${ }^{17}$ Nie pada jednak żadna propozycja. Jeremy Rifkin pisze bardzo dużo o przeciwstawnych cechach Europejczyków i Amerykanów, ale niewiele o czymś, co stanowiłoby treść zalecanego przezeń European Dream. Owszem, mniejszy niż w Ameryce nacisk na pracę, za to większa presja na ochronę środowiska, energie odnawialne, walkę z ociepleniem klimatu itp. Trudno jednak na takich elementach zbudować tożsamość. ${ }^{18}$ Inni autorzy rozprawiający o tożsamości konstruktywistycznej kierują uwagę na „gen socjalizmu”, przejawiający się w społecznej gospodarce rynkowej i państwie bezpieczeństwa socjalnego, czego nie ma w Ameryce..$^{19}$ Jeszcze inni na „dialog”, „otwarcie”, „tolerancję, które nie posiadają konotacji wykluczających w nieuzasadnionym przekonaniu, że na tego rodzaju nastawieniach daje się zbudować jakkolwiek pojmowaną tożsamość zbiorową.

Tożsamość konstruktywistyczna nie odwołuje się do losu, lecz do wyboru. Nie jest dziedziczona, ani narzucana. Jest tworzona przez aktorów życia społecznego. Jest przy tym dynamiczna, zmienna, zorientowana na przyszłość i otwarta na uczestników nieobjętych pierwotnie zakresem tak skonstruowanej tożsamości (tendencje inkluzywne). Konstruktywistyczny typ tożsamości pojawił się na gruncie nowych teorii socjologicznych, zwłaszcza teorii symbolicznego interakcjonizmu, ${ }^{20}$ oraz upowszechniającego się przekonania, że żyjemy w świecie, w którym nasze życie nie jest zdeterminowane przez los, lecz jest rezultatem naszych wyborów. Można sobie wybrać przynależność narodową, system wierzeń, płeć tak, jak od dawna wybieramy zawód, wykształcenie, miejsce zamieszkania itp. Jest jednak pewien problem związany właśnie z tożsamością. Identyfikacja zawodowa może się okazywać zbędna w życiu jednostki, ale już nie identyfikacja z narodem czy wyznaniem. Problem polega na tym, czy można uchodzić za Amerykanina, kobietę, buddystę wskutek

17 Z. Bauman, Tożsamość. Rozmowy z Benedetto Vecchim, GWP, Gdańsk 2007, s. 18.

18 J. Rifkin, Europejskie marzenie. Jak europejska wizja przyszłości zaćmiewa American Dream, Nadir, Warszawa 2005.

19 G. Vattimo, Dom Europa, „Krytyka Polityczna” 2005, nr 5, s. 165; T. Meyer, Die Identität Europas. Der EU eine Seele?, Suhrkamp Verlag, Frankfurt 2004.

20 Przegląd obu stanowisk daje Robert Szwed w: Tożsamość europejska versus tożsamość narodowa? Transformacja tożsamości zbiorowych w Unii Europejskiej, w: Konstruowanie jaźni i społeczeństwa. Europejskie warianty interakcjonizmu symbolicznego, red. E. Hałas, K.T. Konecki, Wydawnictwo Scholar, Warszawa 2005, s. 310-344. 
własnego postanowienia sprzecznego z obiektywnymi, bo ukształtowanymi pochodzeniem i losem wyznacznikami miejsca jednostki w grupie.

Pomysł konstruowania tożsamości zbiorowych wbrew znanym i utartym sposobom ich przejawiania się posiada dwa źródła. Jedno to własna kreacja (konstrukcja) tożsamości indywidualnej. Tożsamość indywidualna, powiada się, jest przedmiotem wyboru, nie jest zdefiniowana przez los. Można sądzić, że podobny wybór, jak jednostki, mają zbiorowości. Drugie źródło kreacji tożsamości zbiorowych wynika z koncepcji tradycji wymyślonych Erica Hobsbawma, ${ }^{21}$ który dowodził, że wiele tradycji narodowych czy regionalnych uchodzących za trwające „od niepamiętnych czasów" jest względnie świeżo wynajdywanych i funkcjonalnie włączanych w obręb tradycji naturalnie historycznych. Można zatem dowodzić, że da się skonstruować sztucznie tożsamość i nałożyć ją następnie na zbiorowość.

To w oparciu o koncepcję Hobsbawma Derrida i Habermas twierdzą, że „[...] wiele tradycji ujmowanych jako naturalne zostało wymyślone".22 Należy się z tym zgodzić, ale nadal nie wynika stąd jakakolwiek konstrukcja tożsamości europejskiej. Jest oczywiste, że np. szlachta polska wymyśliła sarmatyzm, który następnie formował wspólnotę szlachecką, a ruch robotniczy wymyślił święto 1 Maja. W obu jednak wypadkach tradycja, choć wymyślona i sztuczna, zapadła głęboko w świadomość obu wspólnot i określała ich tożsamość. Nic podobnego nie dzieje się w wypadku tożsamości Unii Europejskiej. Wytworzono symbole Unii, prawa podstawowe, wartości europejskie i nadzieję, że brukselskim elitom i biurokratom uda się dotrzeć z tym przekazem do zwykłych Europejczyków. Jest różnica w zestawieniu z podanymi przykładami wymyślonej, ale uwieńczonej sukcesem tradycji. Sarmatyzm i święto 1 Maja przeniknęły do zainteresowanych środowisk, ponieważ były zharmonizowane z ich potrzebami, podkreślały ich wagę i znaczenie w społeczeństwie. Nie były zaplanowanym racjonalnym projektem, który elita nakłada na masy bez względu na ich potrzeby życia. Nie ma dotąd znanych przykładów udanej konstrukcji tożsamości zbiorowej pojmowanej jako zadanie, jako racjonalny projekt. Były próby nieudane. Elita bolszewicka usiłowała zmienić mentalność społeczeństwa rosyjskiego i nadać mu nową tożsamość. Powiodło się to tylko do pewnego stopnia; w każdym razie efektywniej niż w wypadku projektu europejskiego, ale do tego celu komuniści używali aparatu przymusu i zastraszania. Unia nie może sobie na to pozwolić i jest najdalsza od stosowania metod opresywnych.

${ }^{21}$ The Invention of Tradition, red. E. Hobsbawm, T. Ranger, Cambridge University Press, Cambridge 1983.

22 J. Derrida, J. Habermas, op.cit., s. 155. 
Konstrukcja tożsamości europejskiej natrafia właśnie na tego rodzaju problem: czy tożsamość da się skonstruować bez zakorzenienia w przeszłości? Wychodzi się z założenia, że tożsamość europejska nie istnieje, gdyż proces historyczny ukształtował w Europie narody, ale już nie wspólnoty szersze, obejmujące kontynent czy jego część, i uznaje się, że można w oparciu o już dokonane wysiłki integracyjne zbudować wspólnotę, która łączyć będzie jednostki silniej niż naród ukształtowany przez historię. Dotychczas różne całości zbiorowe istnieją z racji własnej autoidentyfikacji, tzn. tożsamość całości zbiorowej poprzedza jej istnienie. Tożsamość stanowi jej esencję. Konstrukcja tożsamości zakłada przebieg procesu w kierunku odwrotnym. Zaistnienie takiej całości, jak powstała dla realizacji interesów gospodarczych i politycznych Unia Europejska, domaga się wykrystalizowania tożsamości Europejczyków, a ponieważ, jak się twierdzi, takiej tożsamości nie ma, trzeba ją nadać. Ponadto twierdzi się, że budowa tożsamości rozumianej esencjalistycznie jest niemożliwa $z$ racji jakoby braku wspólnej historii, kultury, a nawet tradycyjnie rozumianych stałych granic oraz nazbyt wielkiej różnorodności zbiorowości narodowych i ich języków. W świadomości narodów utrwaliła się brytyjskość, germańskość, polskość, ale nie ma jakoby powszechnie podzielanej europejskości. Dlatego konstrukcja tożsamości europejskiej ma polegać na zmianie optyki identyfikacyjnej: łączyć nas ma przyszłość, a nie przeszłość. Za ojczyznę składano ofiarę z życia, dla nowej tożsamości europejskiej warto będzie żyć.

Są jednak wątpliwości. Można sobie per analogiam przedstawić ewentualny podobny wysiłek mieszkańców USA, Kanady i Meksyku zbudowania tożsamości północnoamerykańskiej na bazie integracji gospodarczej w strukturach NAFTA. W tym wypadku byłby to z pewnością twór sztuczny skłócony z tradycjami i przeszłością tych obszarów, zapewne niezdolny do przetrwania. Ale konstrukcja tożsamości europejskiej przez brak zakorzenienia w historii razi sztucznością również. Tożsamość wsparta na wspólnych interesach, odwołująca się do przyszłości, ale pozbawiona emocjonalnej identyfikacji i mistyki przeszłości nie wydaje się trwała, a przy tym jest podatna na wszelkie napięcia zdarzające się w sferze odległej od kultury. Akurat obecny kryzys finansowy stanowi dobrą ilustrację problemu. Euro jako waluta jest z pewnością elementem jednoczącym Niemców i Greków, ale waga tego czynnika jest w obliczu kryzysu niewielka w porównaniu ze wspólnym zakorzenieniem w przeszłości. Sytuacja kryzysu łączy Greków między sobą i Niemców między sobą, czyli wzmacnia tożsamość narodową. Nie łączy jednak strefy euro czy tym bardziej Unii Europejskiej jako całości. Konflikty interesów w takiej sytuacji nie stanowią dobrej przesłanki dla konstrukcji tożsamości. Tożsamość odwołująca się do losu historycznego (esencjalistyczna) wydaje się mieć bardziej ugruntowane podstawy. 
Europejskie elity intelektualne zdają sobie sprawę z występujących problemów, stąd dążenie w konstrukcji tożsamości europejskiej do nowej kreacji przeszłości w ramach polityki historycznej. Obraz przeszłości narodów europejskich miałby być zmieniony poprzez przyjęcie wspólnej europejskiej perspektywy. Zwłaszcza w nauczaniu historii, gdyż trudno zdyscyplinować, jak już się niejednokrotnie dotąd okazywało, profesjonalnych historyków. Przyjęcie wspólnego dla Europy podręcznika historii miałoby w zamierzeniu wychować nowe pokolenie Europejczyków wolnych od narodowych uprzedzeń i stereotypów. Jest to jednak zamierzenie równie niebezpieczne, jak przyjęta wcześniej polityka wielokulturowości, która doprowadziła do konfliktów kulturowych zamiast do zgodnego współżycia. Taka jest właściwie natura projektów europejskich. Są one racjonalne, nacechowane dobrą wolą, odgórnie i sztucznie (administracyjnie) nałożone na społeczeństwa, a efekt jest często odwrotny od zamierzeń.

Spontaniczne wytworzenie tożsamości europejskiej jest możliwe także, a właściwie przede wszystkim na gruncie odziedziczonych tradycji, które wcale nie są tak jednoznacznie narodowe. Zwłaszcza że łatwiej jest budować społeczeństwa obywatelskie z ludźmi w tradycji zakorzenionymi niż od tradycji w zupełności wolnymi. Człowiek przesiąknięty tradycją, jakimś odziedziczonym systemem wartości jest mniej podatny na manipulacje, zestawia bowiem porównawczo czasy i ludzi i na te porównania się orientuje $\mathrm{w}$ obliczu nowych rozwiązań. ${ }^{23}$ Wspólna kultura i tożsamość europejska mogą wyrosnąć na gruncie kultur narodowych bez niszczenia ich. ${ }^{24}$ Nie ma wspólnoty bez tożsamości i jeśli Unia pragnie być wspólnotą, a nie czymś na kształt spółki akcyjnej państw europejskich, musi wytworzyć poczucie tożsamości jako podstawę autorytetu moralnego, do którego mogłaby się odwołać przy próbie podporządkowania indywidualnych państw członkowskich interesom ogółu zwanego „Europą”. Jako wspólnota o wyrazistym autorytecie moralnym Unia miałaby prawo domagać się wyrzeczeń od indywidualnych pracowników i konsumentów dla dobra ogólnego tak, jak dotąd czynią to rządy państw, odwołując się do cnót obywatelskich i uczuć patriotycznych. ${ }^{25}$ Jeśli tak rzeczy wyglądają, to trzeba przyjąć, że nie da się zwyczajnie skonstruować tożsamości przy odwołaniu do tak poczciwych wartości, jak otwartość, tolerancja, dialog itp., które nie cementują więzi społecznych i nie two-

${ }^{23}$ K. Dybciak, Co znaczy katolickość Europy Środkowej?, w: Europa Środkowa: wspólnota czy zbiorowość?, red. R. Zenderowski, Ossolineum, Wrocław-Warszawa-Kraków 2004, s. 27.

24 M. Kuniński, Czy Europejczycy moga być dobrymi obywatelami Unii?, w: Kryzys tożsamości politycznej a proces integracji europejskiej, red. B. Markiewicz, A. Wonicki, Wydawnictwo Naukowe Scholar, Warszawa 2006, s. 99-100.

${ }^{25}$ E. Renan w odniesieniu do narodu podkreślał, że jest on zasadą duchową, solidarnością wspólnoty ustanowioną przez poczucie i gotowość ponoszenia ofiar. Co to jest naród, w: Dzieło Ernesta Renana, Wydawnictwo „Przeglądu Tygodniowego”, Warszawa 1904. 
rzą ducha wspólnoty, z którą identyfikować się może każda jednostka. Europa „jest pewną całością kulturową i cywilizacyjną, posiadającą wspólną historię i tradycję, której pomijanie utrudnia zrozumienie przez Europejczyków ich własnej tożsamości”. ${ }^{26}$ Jak dotąd, Unia Europejska woli pomijać wspólną historię i tradycję, próbując sfabrykować tożsamość na odmiennych podstawach. Do tej chwili bez rezultatu.

Jak pisze Joseph Weiler, „Europa to nie jest manekin, na który można przywdziewać dowolny ubiór". ${ }^{27} \mathrm{~W}$ jednoczącej się Europie problem wcale nie polega na wyprodukowaniu jakiejś tożsamości wspólnej, lecz na wzajemnej akceptacji przez jednostki reprezentujące różne tożsamości narodowe. W istocie problem europejskiej tożsamości wygląda prościej niż to się przedstawia i sprowadza się do akceptacji bliźnich reprezentujących w ramach wspólnoty europejskiej podobne języki, religie, tradycje. Głęboki szacunek, jaki żywimy dla tożsamości własnej: francuskiej, włoskiej, polskiej, pozwala nam utwierdzić szacunek podobny dla innych tożsamości w ramach wspólnoty europejskiej. ${ }^{28}$ Oczywiście, wszystkie wyróżnione atrybuty odróżniają wyraźnie Europejczyków od reszty, w każdym razie od reszty reprezentującej kultury niezachodnie. Dwa narody europejskie mają więcej cech wspólnych na poziomie języka, wartości, religii niż którykolwiek z nich miałby mieć z narodem pozaeuropejskim. Europa poświadcza „odrębność poszczególnych narodów i jedność europejskiej kultury; różnorodność w jedności”. Kraje zredukowane do identyczności zaprzeczałyby duchowi europejskiej kultury. ${ }^{29}$

A jednak wysiłek elit UE kieruje się ku redukcji różnorodności wbrew szumnie głoszonym hasłom. Integracja jest pojmowana często jako uniformizacja. Odnosi się to zwłaszcza do polityki Brukseli wobec tych państw członków, które uprzednio znajdowały się w orbicie wpływów radzieckich. Ich przystąpienie do Unii było motywowane przez nie celami dokładnie przeciwstawnymi tym, które przyświecały ojcom założycielom, czyli dla ochrony niepodległości swoich państw narodowych. ${ }^{30}$ Ingerencje Brukseli w sprawy społeczeństw, krzyże, małżeństwa jednopłciowe itp. stają się przeszkodą w uformowaniu wspólnej tożsamości. Węgrzy w odpowiedzi na wewnętrzny kryzys gospodarczy chcą przebudować swoje państwo na fundamencie wartości chrześcijańskich. Mają do czynienia z umysłowym i duchowym dyktatem europejskiej lewicy. Tak się przejawia hasło „jedność w różnorodności”. Rocco Butiglione nie mógł być nominowany na komisarza KE z powodu ewidentnie chrześcijańskich

\footnotetext{
26 A. Besancon, Zachód przeciwko Zachodowi, „Newsweek” 17 kwietnia 2004.

27 J.H.H. Weiler, Chrześcijańska Europa. Konstytucyjny imperializm czy wielokulturowość?, W drodze, Poznań 2003, s. 107.

28 Ibidem, s. 97.

29 T.S. Elliot, Kto to jest klasyk i inne eseje, Wydawnictwo Znak, Kraków 1999, s. 259.

$30 \mathrm{~J}$. Ralston Saul, The Collapse of Globalism and the Reinvention of the World, Penguin, London 2005, fragmenty w: „Europa” 2006, nr 12.
} 
poglądów. Poglądy jego przeciwnika, pełnokrwistego komunisty nie przeszkadzały większości Parlamentu Europejskiego.

\section{Ewolucja europejskiej tożsamości kulturowej}

Losy zachodniej (łacińskiej) części Europy i jej kultury związane były bezwzględnie z chrześcijaństwem, co najmniej do końca XVII wieku, a do początku XVI wieku z jedną wyłączną wersją chrześcijaństwa. Nie chodzi przy tym o dominację religii, oczywistą przecież, ale o dominację kultury w zupełności nieomal naznaczonej treściami chrześcijańskimi. Kultury, czyli wzorów życia, systemów wartości, standardów cywilizacyjnych itp. Od wieku XVIII rozpoczyna się proces stopniowego odchodzenia kultury europejskiej od wzorów chrześcijańskich w kierunku nowej tożsamości kulturowej, która zostaje tu określona jako indywidualizm ze wszystkimi konsekwencjami i zagrożeniami zeń wynikającymi.

Współczesna kultura europejska osadzona jest już na różnorodności rozmaitych tradycji, których chrześcijaństwo jest jedną z wielu obok tradycji antycznej, tradycji narodowych, laickich nurtów. Niemniej jednak istnieje wspólna podstawa tej różnorodności, wspólny mianownik, pod który podciągnąć się da tak liczne elementy, które kulturę Europy nowożytnej i współczesnej stanowią. Tą podstawą jest jednostka ludzka, która sama kształtuje własny wzór życia i decyduje, z których ewentualnie tradycji, żywych czy martwych, ma skorzystać i czy w ogóle skorzystać z tradycji jakichkolwiek. Ewolucja kultury europejskiej przebiega ku postępującej emancypacji jednostki z jej licznych uwikłań we wszystkich sferach życia: od zależności politycznych, gospodarczych, od autorytetów duchowych, od zniewalających więzi społecznych, upowszechnionych obyczajów czy presji opinii publicznej. Jednostka ma być w pełni autonomiczna i wolna, wyposażona ponadto w liczne uprawnienia, $\mathrm{z}$ którymi się po prostu rodzi. $\mathrm{W}$ języku religii ten sam proces można przedstawić jako ewolucję od transcendencji ku immanencji, od Boga jako nieodłącznego towarzysza ludzkiego losu do człowieka, który odważył się opierać wyłącznie na własnych siłach, ryzykując jednak samotność.

Pojęcie indywidualizmu w sensie kulturowym (bo przecież słowo to występuje w różnych uwikłaniach znaczeniowych) odnosi się do wzoru działania i systemu wartości, w którym jednostka występuje jako wyłączny podmiot własnych decyzji niekrępowanych przez jakikolwiek autorytet, wspólnotę czy władzę publiczną. Definicja ta opisuje stan postulowany przez współczesny zachodni wzór kulturowy, nie 
jest natomiast opisem empirycznym. W obecnej kulturze Zachodu jednostka ma pełne prawo do własnej autonomii, do oparcia się w aktach woli i czynu wyłącznie na autorytecie własnego rozumu, nie znaczy to jednak, że jednostka jest w każdej sytuacji gotowa $\mathrm{z}$ tego prawa skorzystać. Uznaje się tym samym, że podległość autorytetom zewnętrznym bądź wspólnocie w działaniu jest następstwem własnej autonomicznej decyzji jednostki, a nie determinacji kulturowej. W tym sensie jednostka posiada także prawo do przeciwstawienia się czy nieliczenia się z ogólnie przyjętymi normami postępowania, ryzykując, oczywiście, negatywny osąd społeczny czy inne, bardziej surowe sankcje.

Fundamentem autonomii jednostki jest wolność w rozmaitych przejawach życia. Należy jednak pamiętać, że pierwszą chronologicznie wolnością, jaką wywalczyły jednostki w Europie, była wolność sumienia. Wolności obywatelskie i polityczne są znacznie późniejsze. Idea wolności religijnej i sumienia pojawiła się wraz z Reformacją nie ze względu na bardziej tolerancyjne usposobienie reformatorów, ${ }^{31}$ lecz ze względu na wielość wyznań, czego Europa doświadczała po raz pierwszy. ${ }^{32}$ Pierwsze kompromisowe rozstrzygnięcie na terenie Rzeszy Niemieckiej w Augsburgu (1555) wprowadzało zasadą cuius regio eius religio rozwiązanie korzystne dla władców, lecz nie dla indywidualnych sumień. O sto lat późniejszy pokój westfalski (1648) potwierdzał tę zasadę na obszarze państw niemieckich z jednoczesną klauzulą, że władca nie może zakazać poddanym zmiany wyznania. W międzyczasie akt konfederacji warszawskiej (1573) na terenie Rzeczypospolitej i edykt nantejski (1598) we Francji wprowadzały pełniejsze swobody religijne dla dysydentów. Warto odnotować, że były to kraje w znakomitej większości katolickie, a podobnych swobód katolikom nie przyznawano w krajach protestanckich, jak Anglia czy Szwecja, gdzie jeszcze w XIX wieku istniały dla nich ograniczenia prawne. ${ }^{33}$ Warto również nadmienić, że klasyczny orędownik tolerancji, jakim był John Locke (1632-1704), zakreślał jej pewne granice. W dziele opublikowanym w 1689 roku, a pisanym

31 Z całą pewnością byli oni nie mniej przywiązani do swojej wykładni niż przedstawiciele Kościoła katolickiego. Kalwin skwapliwie korzystał ze stosu jako metody zwalczania nieprawomyślnej herezji, a nawet wniósł wkład w techniczne przedłużanie cierpień skazanych nieszczęśników. W swoich zapatrywaniach politycznych domagał się zniesienia zgromadzenia narodowego z racji jego szkodliwości i wyposażenia rządu w narzędzia ścigania nie tylko przestępstw, ale również grzechów i błędów. Prawa średniowieczne były dlań zbyt łagodne, nowe czasy wymagały większej surowości i dlatego bez zastrzeżeń akceptował nieograniczone możliwości, jakie dawała państwu instytucja sądów inkwizycyjnych, pozwalająca np. poddawać podejrzanych torturom nie do zniesienia, nie dlatego, że byli winni, lecz dlatego, że brakowało dowodu ich winy. Por. Lord Acton, Historia wolności w chrześcijaństwie, BMP, Kraków 1995.

32 Naturalnie pluralizm religijny mógł mieć miejsce już znacznie wcześniej, gdyby Kościół okazał gotowość akceptacji wszelkich odchyleń, sprzeciwiałoby się to jednak powołaniu Kościoła.

${ }^{33}$ Jest rzeczą interesującą, że także na gruncie amerykańskim katolicki stan Maryland był pierwszym, który zagwarantował akt o tolerancji religijnej dla wszystkich chrześcijan w roku 1649. 
w okresie rewolucji chwalebnej (1688), ${ }^{34}$ ograniczał jej zasady wyłącznie do chrześcijan, wykluczając ateistów z tej racji, że nie są w stanie szczerze przysiąc na Boga. Ten zapis jest dodatkowo interesujący, jeśli uwzględnić ożywioną działalność w ówczesnej Anglii kwakrów, którzy z zasady odrzucali wszelkie przysięgi. Najwybitniejszy z nich, William Penn (1644-1718), tworzył w tym samym czasie ziemski raj tolerancji religijnej, jakim był stan Pensylwania. Wolności i swobody obywatelskie oraz osobiste jednostek są późniejsze od wolności religijnych przynajmniej o sto lat i tak naprawdę dopiero w epoce Oświecenia otwarcie głoszone, a wprowadzane w życie, poza Stanami Zjednoczonymi, dopiero w następnym stuleciu. ${ }^{35}$

Pochodnymi konsekwencjami tak zdefiniowanego indywidualizmu są w kulturze Zachodu konstytucjonalizm, liberalizm, prawa człowieka, równość, wolność, rządy prawa, demokracja i wiele podobnych idei. Te mogą uchodzić za konsekwencje oczywiste, lecz w nie mniejszym stopniu konsekwencjami indywidualizmu są derywaty oderwane od porządku prawno-politycznego, jak racjonalna postawa w myśleniu i działaniu, wolny rynek czy mobilność w strukturze społecznej. Ogólnie jednak większość osiągnięć w kulturze Zachodu jest następstwem powolnego wzrastania wzoru indywidualistycznego już od Średniowiecza. Istotne jest także, że zagrożenia dla tej kultury wynikają również z indywidualizmu.

\section{Od uniwersalnej tożsamości chrześcijańskiej ku tożsamości narodowej}

W epoce panowania świeckiego indywidualizmu kulturowego chrześcijaństwo rozprzestrzeniające się na całą Europę przestaje być głównym ośrodkiem więzi łączącej mieszkańców kontynentu. W większej mierze funkcję tę spełnia naród i państwo narodowe jako wytwór narodowych aspiracji. $\mathrm{O}$ ile w epoce dominacji powszechnego chrześcijaństwa jedność Kościoła realizowała się w wielości monarchii, o tyle od XVIII wieku państwo narodowe jako ośrodek jednoczący zawiera w sobie wielość kościołów i wyznań.

Historię europejską, powiada się, posiadają i zawłaszczyły narody europejskie z bolesnymi konsekwencjami dla kontynentu jako całości, czego przykładami w przeszłości mają być konflikty, wzajemne uprzedzenia i wojny. Nawet jednak

34 J. Locke, List o tolerancji, PWN, Warszawa 1963.

35 Poza pewnymi swobodami dla arystokracji i miast w Anglii określonymi Wielką Kartą Swobód i gwarancjami typu sądowego, jak Habeas Corpus Act w Anglii czy Neminem captivabimus... w dawnej Rzeczypospolitej. 
w okresie wojen idee, osiągnięcia nauki i sztuki przepływały swobodnie z kraju do kraju. To podstawa stabilnej jedności, fundament trwałych więzi. Co więcej, tak bardzo dziś wychwalany jako osiągnięcie swobodny przepływ ludzi miał miejsce i w przeszłości pomimo istnienia granic państwowych. Do 1914 roku obywatele różnych państw Europy przemieszczali się bez paszportów, wyjątek stanowiła ówczesna Rosja. To była jedność różnorodnego etnicznie kontynentu na fundamencie wspólnych wartości i swobodnych kontaktów ludzkich. Niekiedy mieszane społeczności wytwarzały, jak Czesi, Żydzi i Niemcy w Pradze, zgodną wspólnotę, którą zniszczył dopiero Hitler. Wolne narody i państwa narodowe nie muszą być zagrożeniem jedności i tożsamości Europy. To one tworzyły wspólne wartości europejskie.

Europa była zawsze, dzięki swemu podziałowi i różnorodności, bardziej pluralistyczna niż pozostałe kręgi kulturowe. Wszystko, co olbrzymie i jednokształtne, jest zdecydowanie nieeuropejskie, jak pisał Oskar Halecki. Różnorodność stanowi tajemnicę swoistości cywilizacji europejskiej. Wielkość i liczba same w sobie nie odgrywały w niej większej roli niż różnorodność. ${ }^{36}$ Dzisiejszy świat europejski jest dziedzictwem tamtej historii Europy. Jest to świat suwerennych państw narodowych. W przeszłości podziały wewnętrzne i różnorodność wynikały z warunków geograficznych i różnic etnicznych, rozmaitości języków, których nigdy nie przestano używać mimo wiodącej roli łaciny. Przyszłe narody zaczęly się kształtować już w Średniowieczu i tam też należy szukać źródeł późniejszego nacjonalizmu. Pomimo podziałów i różnic istniała solidarność europejska, nie zawsze na tyle silna, by zapobiec rywalizacji lub zorganizować obronę wspólnej cywilizacji chrześcijańskiej, ale obecna np. w idei krucjat. W czasach nowożytnych solidarność ta przechowała się w poczuciu wyższości Europejczyków i chrześcijan nad innymi kulturami i religiami. Usprawiedliwione czy nie, poczucie takie owocowało roszczeniami do supremacji na polu polityki i gospodarki. ${ }^{37}$

A jednocześnie tak różnorodna cywilizacja europejska była uniwersalna pod względem religijnym, przynajmniej dopóty, dopóki Europa była równoznaczna z chrześcijaństwem. Żadna inna cywilizacja nie obejmowała tak wielu różnych kultur narodowych i jednocześnie żadna inna nie była w równym stopniu uniwersalna, jednocząc kultury narodowe na wspólnym pniu chrześcijaństwa. W okresie nowożytnym uniwersalność ta w mentalności europejskiej wychodziła także poza Europę i obejmowała ludy pozaeuropejskie w złudnym przeświadczeniu, że kultura europejska zawiera wartości stanowiące dla nich wzór. Ta iluzja przetrwała zresztą w nieustających napomnieniach kierowanych do pozostałych cywilizacji, jak mają zmieniać

36 O. Halecki, Historia Europy - jej granice i podziaty, Instytut Europy Środkowowschodniej, Lublin 2002, s. 28.

37 Ibidem, s. 53-55. 
wzory swojego życia, by osiągnąć sukces cywilizacyjny i przede wszystkim dlaczego mają u siebie zaszczepiać prawa człowieka, których te cywilizacje uprzednio nie znały ze względu na odmienność własnych tradycji. Napomnienia te mają miejsce pomimo utraty przez Europę wiodącej pozycji na świecie i uderzającego spadku atrakcyjności własnych wzorów kulturowych w oczach przedstawicieli nieeuropejskich kultur.

W długiej historii Zachodu ukształtowały się kolejno następujące po sobie epoki wspólnoty śródziemnomorskiej (świat grecko-rzymski), wspólnoty europejskiej (V-XX wiek) i wreszcie wspólnoty atlantyckiej powstałej w obliczu zagrożenia komunistycznego po II wojnie światowej. Powojenna integracja Europy jako części Zachodu ma miejsce już w warunkach zmierzchu dominacji europejskiej. Tego rodzaju periodyzacja w terminach „długiego trwania” ${ }^{38}$ pokazuje, że wbrew argumentom dowodzącym świeżego historycznie powstania i kształtowania się wspólnoty europejskiej jej historia jest długa i zakorzeniona w doświadczeniu narodów europejskich. To jest podstawa rzeczywistej tożsamości wynikłej ze wspólnoty historycznego europejskiego losu. Jest prawdą, że w pamięci Europejczyków przechowuje się w większym stopniu świadomość narodowa niż świadomość przynależności europejskiej. Ale przecież silniejsza niż tożsamość narodowa okazuje się niekiedy świadomość przynależności regionalnej obudowana wokół silnej identyfikacji emocjonalnej opartej na związkach osobistych. Te trzy ośrodki tożsamości zbiorowej: region, naród i Europa nie muszą być ujmowane jako opozycyjne, mogą się wzmacniać wzajemnie. Naturalnie w sytuacji konfliktu interesów powodowanych przynależnością do różnego poziomu kręgów koncentrycznych nie należy się spodziewać, że Belg postawi interes Europy ponad interesem Belgii, a Flamand interes Belgii ponad interesem Gandawy czy Brugii. Podobnie jest w przypadku religijnej przynależności do parafii, diecezji i Kościoła powszechnego. Istnieje tożsamość chrześcijańska określona przez identyfikację z Kościołem, nawet jeśli wierni odznaczają się nastawieniami wyraźnie parafiańskimi.

Nie przesądzając zatem jej siły, istnieje tożsamość europejska zdefiniowana przez wspólne dziedzictwo, w którym Europejczycy uczestniczyli. Jest to wspólnota losu, w przeszłości wzmacniana przez konfrontację i rywalizację ze światem zewnętrznym, jak w epokach krucjat, obrony przed ekspansją turecką czy kolonizacji. Nie tylko narody mają własną historię, ma ją również kontynent pomimo licznych konfliktów narodowych na jego obszarze. Identyfikacja europejska nie jest czymś, co trzeba dopiero stworzyć czy skonstruować, jest to fakt współwystępujący z tożsamością narodową i regionalną. Ewentualna eliminacja narodów w Europie, niewyobrażalna

38 Ujęcie procesu historycznego w terminach "długiego trwania” wprowadza Fernand Braudel, Historia i trwanie, Czytelnik, Warszawa 1971, rozdz. Historia i nauki społeczne; długie trwanie. 
zapewne, nie pogłębiłaby poczucia europejskiej tożsamości, gdyż ludzie z natury wolą się identyfikować z czymś bliższym, bardziej swojskim. Istnienie i stosunkowo wczesne wykształcenie się narodów stanowi specyfikę historii europejskiej, jej różnorodność z ujawnianiem się dążeń do osiągnięcia jedności. Europa to sklepienie narodów. Przy tym dzisiejsze europejskie państwa narodowe nie są już nacjonalistycznymi, potencjalnie wrogimi krajami. Przemierzyły proces modernizacji, są bardziej otwarte i elastyczne, także we współpracy międzynarodowej.

\section{Chrześcijaństwo i świecka racjonalność jako źródła tożsamości}

Wspólnota europejskiego historycznego losu kształtowała się na bazie wartości wspólnych przyjętych przez wszystkie narody wchodzące w skład zachodniego chrześcijaństwa. Jest to ważne, ponieważ chrześcijaństwo łacińskie stanowiło pierwotną podstawę do kształtowania się wzorów życia i organizacji społecznej, które okazały się historycznie trwałe. Historyczna Europa była chrześcijańska w odmianie łacińskiej. Dziedzictwo to zostało następnie przefiltrowane w epoce Oświecenia, ale pomimo wszelkich napaści tej epoki wobec chrześcijaństwa wiele elementów składających się na wcześniejszą tradycję nie zostało naruszonych. I tak podkreślane $\mathrm{w}$ przesłaniu chrześcijańskim idee poskromienia natury, postępu czy etosu pracy zostały przez prądy oświeceniowe wzmocnione. Monteskiuszowski, konstytucyjny podział władz był poprzedzony wielowiekowym dwubiegunowym układem władz $\mathrm{z}$ ich podziałem na władze świeckie i duchowne i bez tego poprzedzającego i historycznie trwałego podziału zapewne pomysł rozdzielenia władz w państwie by się nie narodził. W tym sensie nowoczesne państwo konstytucyjne i świeckie społeczeństwo liberalne wypływają z ducha chrześcijańskiego, choć były tworzone w opozycji wobec religii i Kościoła.

Jeśli się zgodzić z opinią, że Oświecenie gruntownie przeorało wcześniejszą tradycję chrześcijańską będącą fundamentem jedności europejskiej, to należy też zauważyć, że podobny do Oświecenia nurt nie wystąpił w żadnym innym kręgu kulturowym, nie wyłączając chrześcijaństwa wschodniego odznaczającego się odmiennym wzorem ułożenia relacji między władzą państwową i kościelną. A przy tym korzenie Oświecenia w Europie daje się odnaleźć już w głębokim Średniowieczu. Wtedy na uniwersytetach miała miejsce scholastyczna recepcja racjonalności. Wtedy też tworzyła się autonomiczna i wolna społeczność miejska, której nie znajdzie się w Bizancjum, społeczeństwach muzułmańskich czy w Chinach. Wreszcie w Europie już 
w Średniowieczu rozwijało się, w nawiązaniu do tradycji rzymskich, prawo i tworzone były podstawy porządku prawnego oraz państwa prawa. W tamtej Europie kształtowała się zatem racjonalność, kultura miejska oraz państwo prawa. Nieco później zaczęły się wyodrębniać narody i kształtować instytucje demokratyczne. Podstawy nowożytnego porządku uformowały się w Średniowieczu.

Z pewnością we współczesnych rozważaniach tyczących się tożsamości europejskiej dominuje tradycja oświeceniowa, która powątpiewa w ogóle w wartość tradycji jako takiej, a tradycjonalizm ujmuje jako barierę na drodze ukształtowania się właściwej tożsamości europejskiej. Jednak właśnie kryzys tradycji zagraża w największym stopniu europejskiemu poczuciu własnej tożsamości. Przy tym sama tradycja oświeceniowa nie powstała jako samorodne dzieło „oświeconych umysłów”, lecz wynikała z wcześniejszych, nowożytnych i nawet jeszcze średniowiecznych poszukiwań. Bez średniowiecznej scholastyki, bez chrześcijaństwa nie byłoby ani Woltera, ani Nietschego. ${ }^{39}$

Wybitny reprezentant wczesnego romantyzmu niemieckiego Friedrich Leopold von Hardenberg (Novalis) napisał w roku 1799 krótki i słynny esej Die Christenheit oder Europa ${ }^{40}$ Dowodził w nim, że chrześcijaństwo nadało tożsamość Europie i że sukces Oświecenia zniszczył tę tożsamość, którą jednak będzie można zawsze odnaleźć jako ideał. Oba żywioły, chrześcijański i oświeceniowy, prowadzą od tego czasu walkę o duszę Europy. Zdegenerowana Europa pooświeceniowa to rezultat kontraktu, „umowy społecznej”, którą Novalis uznał za fikcję, negując możliwość ukonstytuowania się wspólnoty politycznej w wyniku „decyzji” jej członków. Przeciwstawiał jej autonomię miast i innych wspólnot z okresu Średniowiecza. Dowodził, że naszej egzystencji nadaje sens świadomość istnienia rzeczywistości nadprzyrodzonej, która jest jedyną gwarancją ludzkiej wolności i godności, a którą Oświecenie zniszczyło, otwierając drogę egocentryzmowi jednostki przeciw wspólnocie.

Obecnie świecka racjonalność, spuścizna Oświecenia, i chrześcijaństwo o znacznie dłuższej tradycji to dwie kontrastowe formacje duchowej tożsamości Europy. Obie uważają się za uniwersalne, choć „uczestniczy w nich tylko część ludzkości i tylko dla części ludzkości są one zrozumiałe" ${ }^{41}$ Obie są jednak nieuniwersalne, rozmijają się bowiem z tradycjami islamu, Indii oraz Chin. Obie tradycje Zachodu są w konflikcie wewnętrznym. Choć świecka kultura ścisłej racjonalności ma dziś charakter

\footnotetext{
39 T.S. Elliot, op.cit., s. 262.

40 Novalis, Chrześcijaństwo, czyli Europa, przeł. J. Prokopiuk, w: Państwo a społeczeństwo. Wizje wspólnot niemieckich od oświecenia do okresu restauracji, wybór i oprac. T. Namowicz, Wydawnictwo Poznańskie, Poznań 2001, s. 312-330.

41 J. Ratzinger, Rozum dotarł do swoich granic, „Newsweek” 10 kwietnia 2004; debata Ratzinger-Habermas Rozum i wiara Zachodu w Katolickiej Akademii Bawarii.
} 
dominujący, to chrześcijaństwo nadal pozostaje liczącą się siłą. Przeciwstawne bieguny kultury Zachodu zbliżają się czasem do siebie, to znów oddalają, odmawiając sobie nawzajem prawa do istnienia. Świat zewnętrzny, przywiązany do swoich religii i tradycji, tego nie rozumie. Laicka racjonalność zachodnia z przesłaniem praw jednostki propaguje, bez rezultatu, swoje wartości w świecie pozazachodnim, musi jednak dojrzeć do przekonania, że tych wartości „nie da się jej zaszczepić całej ludzkości i że w związku z tym nie może ona funkcjonować wszędzie z równym sukcesem, co na Zachodzie. [...] Racjonalna, etyczna czy religijna formuła stanowiąca propozycję dla całego świata nie istnieje". ${ }^{42}$

Współczesna Europa, i szerzej Zachód, ujawnia jako całościowa kultura szczególną swoistość pośród wszystkich znanych kultur. Jak wywodzi Arnold Toynbee, każda kultura czy cywilizacja w dotychczasowych dziejach ludzkości obudowana była wokół konkretnej religii. Pod tym względem postoświeceniowa kultura Europy staje się ewenementem jako kultura zbudowana na w pełni świeckich wartościach. W opinii wybitnego historyka jest to projekt pasożytniczy, ponieważ wykorzystuje (nie przyznając się do zapożyczenia) budulec chrześcijański, a zarazem podmywa chrześcijańskie podstawy całej konstrukcji. ${ }^{43}$ Przyszłość tak skonstruowanego projektu nie zapowiada się pomyślnie, zwłaszcza w konfrontacji z innymi cywilizacjami. Historia Europy jest „[...] wielką rzeką, do której wpadają rozliczne dopływy i strumienie, a różnorodność tworzących ją tradycji i kultur jest jej wielkim bogactwem. Zrąb tożsamości Europy jest zbudowany na chrześcijaństwie. A obecny brak jej duchowej jedności wynika głównie z kryzysu tej chrześcijańskiej samoświadomości”. ${ }^{44}$

\section{European identity as historical and present day problem}

Christianity, filtered through the heritage of Enlightenment, is a founding stone of European identity. Western Christianity is of particular importance here, as only in the region it dominated we can speak of Enlightenment and periods that precede it, that is Renaissance and Reformation. European Union is primarily constituted by countries that are culturally related to Western (Latin) Christianity.

\footnotetext{
42 Ibidem.

43 A. Toynbee, Cywilizacja w czasie próby, tłum. W. Madej, Wydawnictwo Przedświt, Warszawa 1988.

${ }^{44}$ Jan Paweł II, Nie będzie jedności Europy, dopóki nie będzie ona wspólnota ducha, homilia wygłoszona w Gnieźnie w dniu 3 czerwca 1997 roku z okazji 1000. rocznicy śmierci św. Wojciecha, „L' Osservatore Romano" (wyd. polskie) 1997, nr 7.
} 
Enlightenment (secular rationalism) as such was not sufficient for creation of European identity.

The paper describes the evolution of European identity closely linked with Christianity, that was later on left for rationalism and national identities. I try to prove that the identity of Europeans is historically closely linked to the diversity of nations that constitute Europe and that a national identity serves to underline European Community rather than deny it.

Existing European identity has its roots in common history, contrary to popular believes that Europeans identify only with their nations. The paper also explains why new European identity needs to be constructed in relation to common European past and not in relation to the future of Europe.

\section{Европейское тождество как проблема истории и современности}

Фундаментом европейского тождества является христианство, в дальнейшем профильтрованное через наследство Просвещения, которое подавило первоначальную христианскую традицию. Тем не менее, основные европейские ценности происходят, несмотря на просветительные переоценки, от традиции западного христианства; так как только в этом пространстве появились просветительные течения и предшествующие им течения Ренессанса и Реформации, а Европейский Союз по сути составляют страны культурно принадлежащие к западному христианству (латинскому). Невозможно построить европейское тождество на основе только наследства Просвещения (светской рациональности).

В работе описана эволюция европейского тождества в неотъемлемой связи с христианством и ухождением к светской рациональности и национальной идентификации. Доказываться, что тождество европейцев имеет тесную историческую связь с разнородностью наций создающих Европу и что национальное самосознание является скорее укрепленем чем отрицанем европейской общности.

Вопреки часто провозглашаемым утверждениям об исключительно национальных идентификациях европейцев, существует европейское тождество вытекающее из общности исторической судьбы. Кроме того, в разработке поднимается аргументы против попыток сконструирования нового европейского коллективного тождества, основаного на стремлениях в будущем, а не на европейском историческом опыте. Традиционно понимаемому тождеству судьбы противопоставляется тождество произходящие «из присвоения» или выбора. 